\title{
Notes on the taxonomy of Spiraea aemiliana and related species (Rosaceae) in Russia
}

\author{
Vera Kostikova*, Victoria Troshkina \\ Central Siberian Botanical Garden, SB RAS, Str. Zolotodolinskaya, 101, Novosibirsk, 630090, Russia
}

\begin{abstract}
The diversity of the plants of Spiraea genus, Calospira section in terms of the morphological characters on the basis of 28 natural populations was studied. Two species of Calospira section spirea grow in the Asian part of Russia (S. betulifolia Pall. and S. beauverdiana C.K. Schneid.). S. betulifolia Pall. subsp. aemiliana (C.K. Schneid.) H. Hara subspecies grows on the Islands in the Asian part of Russia (Sakhalin and the Kuril Islands). Its distinctive features are small round or spatulate (obovate) lamina and the absence of the inflorescence follicles pubescence, as well as a few metrical characteristics that may be auxiliary in determining the taxon.
\end{abstract}

\section{Introduction}

The research of a polymorphous species complex S. betulifolia Pall. - S. beauverdiana C.K. Schneid., the plants of Spiraea genus, Calospira section in Asian part of Russia confirmed the existence of 2 species. S. beauverdiana differs from $S$. betulifolia in having dense pubescence of the pedicles and the follicles and the curved position of the follicle rostrum. Two studied species of Spiraea genus of Calospira section are indistinguishable in terms of quantitative morphological characters. The qualitative composition of the phenolic compounds in aqueous ethanol extractions from spirea leaves is species-specific $[1,2]$. Some researchers mark out one more species $S$. aemiliana C.K. Schneid. as a subset of the polymorphous complex $S$. betulifolia $-S$. beauverdiana. This taxon has low height up to 30 $\mathrm{cm}$ and round coin-shaped leaves. In terms of the habit it is closest to S. beauverdiana. Besides Russia, it also grows in Japan [3]. C.K. Schneider [4] described this species from his research in the high-mountains of Hokkaido, Japan. S. aemiliana was described as a separate species by V. N. Voroshilov [5, 6] in the «Flora Sovetskogo Dalnego Vostoka» and the «Opredelitel rasteniy Sovetskogo Dalnego Vostoka». G. Koidzumi [7] ascribed to this species the rank of a variety of S. betulifolia Pall. var. aemiliana (C.K. Schneid.) Koidz., considering it a synonym of $S$. beauverdiana. The same point of view was expressed by J. Ohwi [8] in the «Flora of Japan» and H. Ikeda [9] in his «Flora of Japan». H. Hara [10] transferred this taxon into the rank of $S$. betulifolia Pall. subsp. aemiliana (C.K. Schneid.) H. Hara. V.V. Yakubov [11] noted that on the Southern Kuril Islands one can frequently see a type of $S$. betulifolia with small coin-shaped leaves, which has the appearance similar to the kin species $S$. beauverdiana, differing from it in having completely bare

\footnotetext{
*Corresponding autor: serebryakova-va@yandex.ru
} 
inflorescence pedicles. In the opinion of N. N. Tsvelev [12], shortgrowing, parvifolious and almost void of pubescence $S$. betulifolia samples from Kunashir Island deserve an independent species' rank which he had denotated as the new $S$. vorobjevii Tzvelev species.

\section{Materials and Methods}

In the Asian part of Russia, S. betulifolia has been collected from 17 populations and S. beauverdiana from 7 populations in 2003-2017 in Amur, Magadan, Sakhalin and Kamchatka regions, the Jewish Autonomous Oblast, Khabarovsk Krai, Primorski Krai and the Republic of Yakutia. The populations of plants with $S$. aemiliana habit has been collected in two locations on Kunashir Island (the «Kislaya» and the «Kipyashchaya» populations). Each of the population includes not less than 30 specimens. All the collecting was done in July and August, during the follicle ripening period. To study the morphological variability, we selected the qualitative and the quantitative characteristics of the most functionally significant organs: the lamina, blossom clusters and the stalks [13]. The shape of the lamina was determined by the criteria which had been developed earlier [14].

\section{Results and Discussion}

We discovered the plants with the typical small and round shape of the lamina only in the «Kislaya» and the «Kipyashchaya» populations from the Kunashir Island (see the Table). We have not discovered such a lamina anywhere else. The round shape of the lamina prevails in these plants. Also, comparatively small spatulate shape of the lamina has been noted in these populations. The plants from the «Kislaya» and the «Kipyashchaya» populations do not differ from $S$. betulifolia by any other qualitative characteristics. No significant differences in quantitative characters have been discovered. The plants from the «Kislaya» and the «Kipyashchaya» populations have smaller mean values of some metrical characteristics, and they do not overlap with the mean values of $S$. betulifolia and S. beauverdiana: «The length of the leaf», «The distance from the leaf base to the widest part of the leaf», "The petiole length», while the relative characteristic «The relative lengthto-width ration» and «The ratio of the bud length to the petiole length» are noted more in S. aemiliana. However, the scope of the abovementioned characteristics in the plants of the «Kislaya» and the «Kipyashchaya» samples fit with the variability amplitude of $S$. betulifolia and $S$. beauverdiana. The putative $S$. aemiliana plants are closer to $S$. beauverdiana in terms of its quantitative characteristics.

Besides, the genome size of the studied spirea and the chemotaxonomy have been researched. The values of the relative DNA content in the spirea are reliably different with high statistical significance $(\mathrm{p}<0,001)$. The relative DNA content in $S$. betulifolia $(2 \mathrm{C}=$ 0,91 and $1,01 \mathrm{pg}$ ) is two times higher than the corresponding values for other species. $S$. beauverdiana $(2 \mathrm{C}=0,55$ and $0,5 \mathrm{pg})$ and the putative $S$. aemiliana $(2 \mathrm{C}=0,45$ and 0,48 $\mathrm{pg}$ ) are more related taxons in terms of DNA content [15]. The study of the interpopulation variability of the Calospira spirea in terms of phenolic compounds demonstrated that $S$. betulifolia is different from $S$. beauverdiana in the rutin and avicularine content in waterethanol extractions from the leaves. Additional components which are absent in $S$. betulifolia have been discovered in $S$. beauverdiana leaves. The putative $S$. aemiliana samples are not much different from $S$. betulifolia sample in terms of the phenolic compounds content, however, the $S$. aemiliana leaves contain isoquercitrin absent in $S$. betulifolia and S. beauverdiana [16].

Thus, we should mark out a separate $S$. betulifolia subsp. aemiliana, which is rather 
different in having small round lamina shape on the basis of the research conducted in Russia. This taxon does not differ from $S$. betulifolia in terms of other qualitative characters and is close to $S$. beauverdiana in its quantitative characters.

Table. Variability in the shape of lamina of the Spiraea genus, section Calospira

\begin{tabular}{|c|c|c|c|c|c|}
\hline & & & hape of lan & & \\
\hline & Ellipsoidal & Ooidal & Diamond & Spatulate & Rounded \\
\hline Taxon & & & & & \\
\hline S. betulifolia & + & + & + & + & - \\
\hline S. beauverdiana & + & + & - & - & - \\
\hline «Kislaya» & - & - & - & + & + \\
\hline «Kipyashchaya» & - & - & - & + & + \\
\hline
\end{tabular}

We provide the main synonyms for the abovementioned taxons of Spiraea genus, Calospira section and the key for their determination on the basis of the conducted research.

Spiraea betulifolia Pall. 1784 in Fl. Ross. 1(1): 33; ej 1789 in Fl. Ross. 1(1): 75; Poyark., 1939, in Fl. USSR 9: 288, s. str.; Ohwi, 1965, in Fl. Japan: 521, s. str.; Voroshilov, 1966, in Fl. Sovetsk. Daln. Vost.: 249; Vorobiev, 1968, Dikorastushchiye derev. i kust. Daln. Vost.: 118; Voroshilov, 1982, in Opredel. rast. Sovetsk. Daln. Vost.: 337; Polozhiy, 1988, in Fl. Sib. 8: 14; Yakubov, 1996, Sosud. rast. Sovetsk. Daln. Vost. 8: 134, s. str.; Koropachinsky, Vstovskaya, 2012, Drevesn. rast. Aziatsk. Ros.: 384; Tsvelev, 2008, in Novosti Sist. Vyssh. Rast. 40: 80.

S. betulifolia Pall. subsp. aemiliana (C.K. Schneid.) H. Hara, 1951, J. Fac. Sci. Univ. Tokyo, Sect. 3, Bot. ser. 3, Bot. 6: 77. $\equiv$ S. aemiliana C.K. Schneid. 1905, Bull. Herb. Boiss. Ser. 2. T. 5(4): 347; Voroshilov, 1966, in Fl. Sovetsk. Daln. Vost.: 349; he is, 1982, in Opredel. rast. Sovetsk. Daln. Vost.: 336. $\equiv$ Spiraea betulifolia Pall. var. aemiliana (C.K. Schneid.) Koidz., 1909, Bot. Mag. (Tokyo) 23: 166; Ohwi, 1965, in Fl. Japan: 521.

S. beauverdiana C.K. Schneid. 1905, in Bull. Herb. Boiss., 2 ser. 5: 348, incl. var.; Poyark., 1939, in Fl. USSR 9: 289; Voroshilov, 1966, in Fl. Sovetsk. Daln. Vost.: 249; Vorobiev, 1968, Dikorastushchiye derev. i kust. Daln. Vost.: 120; Polozhiy, 1988, in Fl. Sib. 8: 12; Yakubov, 1996, Sosud. rast. Sovetsk. Daln. Vost. 8: 134; Tsvelev, 2008, in Novosti Sist. Vyssh. Rast. 40: 81, hybr.; Koropachinsky, Vstovskaya, 2012, Drevesn. rast. Aziatsk. Ros.: 383. $\equiv$ S. stevenii (C.K. Schneid.) Rydb. 1908, in N. Amer. Fl. 22(3): 247; Voroshilov, 1966, in Fl. Sovetsk. Daln. Vost.: 250; Vorobiev, 1968, Dikorastushchiye derev. i kust. Daln. Vost.: 120; Tsvelev, 2008, in Novosti Sist. Vyssh. Rast. 40: 80.

\section{The key to the taxons of Calospira section in Russia}

1. Pedicles and follicles are bare, or with scarce or single pubescence, the rostrum of follicle is straight............................................................. 3

2. Pedicles and follicles have dense and wooly pubescence, the rostrum of follicle is curved..............................................................................

3. The stem length is bigger than the bud length, the leaves have ooidal, ellipsoidal, 
spatulate or diamond shapes.

S. betulifolia

4. The stem length is equal to the bud length, the leaves are small and of round or spatulate shape ........................................ betulifolia subsp. aemiliana 5. The stem equals the bud in length, the leaves are of ellipsoidal or ooidal shape. S. beauverdiana

\section{Conclusion}

The authors have studied the diversity of the Calospira section spirea in terms of the quantitative morphological characters on the basis of 28 natural samples. The key has been made for the identification of species. Two species of Calospira section spirea grow in the Asian part of Russia ( $S$. betulifolia and $S$. beauverdiana), which most probably used to be 2 ecotypes of the same species some time ago. S. betulifolia subsp. aemiliana subspecies grows on the Islands in the Asian part of Russia (Sakhalin and the Kuril Islands). Its distinctive features are small round or spatulate (obovate) lamina and the absence of the inflorescence follicles pubescence, as well as a few metrical characteristics, the average values of which do not overlap with $S$. betulifolia and $S$. beauverdiana average values. This taxon has a trend towards stabilization of morphological characteristics, but has not yet sufficiently separated from $S$. betulifolia.

The reported study was funded by RFBR according to the research (project No. 16-3400106 мол_a to Kostikova)

\section{References}

1. V.A. Kostikova, T.A. Polyakova, Contemp. Probl. of Ecol., 7, 3 (2014)

2. V.A. Kostikova, T.A. Polyakova, Bull. of Mosc. Soc. of Natur., 4 (2018)

3. D.P. Vorobiev, Wild trees and shrubs of the Far East. Determ. (Nauka, L. 1968)

4. C.K. Schneider, Bull. Herb. Boiss., 5, 4 (1905)

5. V.N. Voroshilov, Flora of the Soviet Far East (Nauka, M., 1966)

6. V.N. Voroshilov, Determ. of plants of the Soviet Far East (Nauka, M., 1982)

7. G. Koidzumi, Bot. Mag. Tokio, 23 (1909)

8. J. Ohwi, Flora of Japan (DC: Smithsonian Institution, Washington, 1965)

9. H. Ikeda, Flora of Japan, 2 b (Tokyo, 1995)

10. H. Hara, J. Fac. Sci. Univ. Tokyo, 3, 6 (1952)

11. V.V. Yakubov, Vascular plants of the Soviet Far East, 8 (Nauka, St. Petersburg, 1996)

12. N.N. Tsvelev, Systematics news of higher plants, 40 (2008)

13. T.A. Polyakova Intraspecific variability of the Far Eastern and Siberian species of the genus Spiraea L .: PhD thesis (SB RAS, Novosibirsk, 2004)

14. A.A. Fedorov et al. Atlas on descriptive morphology of higher plants. Sheet (Edition of the USSR AS, M. - L., 1956).

15. V.A. Kostikova, M.S. Voronkova, E.V. Banaev, T.A. Polyakova, Botan. Pacif., 7(1) (2018)

16. V.A. Kostikova, Mat. of the VI Internat. Scient. Conf. dedicated to the 100th anniversary of Prof. A.V. Polozhiy (State University Publishing House Tomsk, Tomsk, 2017) 